\title{
Impact of ACFTA on Trade Creation and Trade Diversion of Fruit Industry
}

\author{
Linh T.D. HUYNH ${ }^{1 *}$ and Oanh T.K. HOANG ${ }^{1}$ \\ ${ }^{1}$ Department of International business, University of Economics, The University of Danang, Danang, Vietnam. \\ *Corresponding author: linhhtd@due.edu.vn
}

\begin{abstract}
This article examines the trade creation and diversion effects of ASEAN-China free trade agreements (ACFTA) for fruit industry by estimating the gravity trade model for the period between 2002 and 2016. The paper uses the pa nel-data with Generalized Least Square (GLS) estimate. The estimated results show that the trade creation has an effect on fruit item. The trade creation effect in ACFTA might come from the wider gap between the general tariff rate and the preferential tariff rate for ASEAN and China fruits, the close distance between commercial partners a nd the conversion of certificate of origin $(C / O)$ of goods to export.
\end{abstract}

\section{Research purpose:}

Evaluating the impact of the ACFTA on the export of fruit to ACFTA member countries. Contributing to the literature on the impact of the FTA on the trade flows of member countries, in particular the export and import of Vietnamese fruit with China following the accession of the ACFTA trade liberalization agreement.

\section{Research motivation:}

In recent years, import - export balance, which affects national economy, is always considered as one of the most important item by the government. Moreover, facing with Covid-19 Pandemic during these 2 -recent years, the threat of a frozen, import- export industry is getting more attentions. Despite of the serious epidemic, Vietnam's import- export balance has been rising steadily, which in turn encourages us to pay more attention to industry development.

Free trade agreements are rapidly increasing in recent years, represented by more and more bilateral and multilateral trade agreements being established. By participating in international and regional trade organizations, Vietnam is also gradually integrating into this trend. It not only opens a new opportunity for the country's economic development and expanding export markets but also helps Vietnam become more involved in the value chain, creating a global production network, transforming the economic structure in a positive way and improving the business environment. New generation FTAs are putting Vietnam ahead of a new trade platform through making strategic changes to enhance economic cooperation and removing previous tariff barriers that hamper the nation-to-nation trade process. FTAs help Vietnam enjoy less-tariff and non-tariff preferential treatment, and also have conditions for more balanced restructuring of import and export markets, avoiding excessive dependence on certain markets.

China is Vietnam's large and potential trading partner. Vietnamese companies want to improve their ability to access the Chinese market gradually. In order to take advantages of Free Trade Agreements (FTAs) with China, Vietnam needs to understand the opportunities and benefits as well as the challenges of these FTAs. Therefore, ASEAN-China Free Trade Agreements should be of interest.

\section{Research design, approach and method:}

This article is organized in the following way. Section 1 is an introduction about this research. Section 2 reviews some previous studies. Section 3 describes data and methodologies. Section 4 shows the empirical results. Final section includes summary and conclusions.

The paper applies the panel-data with Generalized Least Square (GLS) estimate.

\section{Main findings:}

The trade creation effect in ACFTA might come from the wider gap between the general tariff rate and the preferential tariff rate for ASEAN and China fruits

Keywords: trade creation, trade diversion, ASEAN-China free trade agreement, agricultural trade, gravity mode. 


\section{INTRODUCTION}

"The custom union issue" (Viner, 1950) Viner's book published since 1950s defined for trade diversion and trade creation. This is the first research about it. Viner introduced the theories 'trade creation' and 'trade diversion' which became necessary instruments for the analysis and realizing of the effects of an economic integration. Viner (1931) explained that: The shift from cheaper to more expensive producers in trade is trade diversion, while trade creating is increasing the volume of trade between countries when they agree to set up a custom union.

Any Free Trade Agreement (FTA) is strongly associated with lower trade barriers between member countries. Therefore, not only can create new trade between members of the agreement, but can also divert trade from less expensive to more expensive producers of the same product (Viner, 1950). Trade creation happens when new trade arises as a result of reducing trade barriers between FTA members. However, Trade diversion occurs when trade moves from a tradition exporter to a more inefficient one because of lower tariffs between member countries (Kendall, 2007).

These two studies assist us in comprehending and gaining insight into international trade flows. Assist us in defining what it means of trade creation and trade diversion, as well as the impact of them.

In the past decade, more and more bilateral and multilateral free trade agreements have been signed. It is expected that these trade agreements will increase trade in goods between member countries. It not only it can create new trade between members of the agreement, but it can also divert trade from less expensive to more expensive producers of the same product (Viner, 1950). Therefore, some people have conducted research on the effects of trade agreements on the creation and diversion of trade between member states by applying Gravity model which is a common method to evaluate effect of FTA. The gravity model has become an important and effective tool to assess the trade flows of the two countries. The two main variables used in the gravity model are GDP and Distance. Besides, other variables are also added into the model such as common language or population depending on the research purpose of the authors.

Starting by the study of Anne O. Krueger (1999), they used a gravity model to evaluate NAFTA's impacts on trade flow of member countries. He used trade data between the United States, Canada and Mexico tried to assess the initial impact of entry into Mexico on NAFTA form 1987 to 1997 with 61 countries by using a panel data. Results showed that there was a positive increase in trade between USA and Mexico after the NAFTA agreement was signed and in effect. NAFTA creates trade creation for member countries instead of trade diversion (Krueger, 1999).
According to the research by Adriano Giacomini Morais Siegfried Bender (2003), they contributed ideas on trade diversion and trade creation through research on Mercosur and NAFTA. This study was conducted with the aim of evaluating the impact on trade diversion and trade creation of the two agreements: Mercosur and NAFTA. Conducted a research by using gravity model and penal data methods. Research is based on data of export value of 57 countries. In this study, data were collected from 1980 to 2002. The logarithm of trade flows are explained by the total GDP of both countries, distance between them, population, exchange rate and free trade agreement. The results showed that no trade creation occurred in both agreements. Thinking about the trade-agreement relationship, the authors give opinions that participating in the free trade agreement tend to be related to trade flows of member countries (Adriano Giacomini Morais; Siegfried Bender, 2003).

Turning to Christopher S. P. Magee (2004), he expressed his contribution through research about Endogenous Regionalism. The objective of this paper is to assess the impact of participation in trade agreements on the trade creation and trade diversion by member country. This article assumes that countries that participate free trade agreement and have a close in geographic will lead to trade diversion rather than trade creation. The results of the study serve as an advice on the decision that countries make about joining free trade areas. They evaluated this effect between years between 1985 and 1994 and considered whether the factor caused trade diversion and trade creation. This result also shows that, countries which have common border will have a higher level of trade flows. The proliferation of free trade agreements (FTAs) raises questions about their impact on FTA countries and worldwide (Magee, 2004).

Meanwhile, Baltagi, Egger, and Pfaffermayr (2007) examine the relationship of regional trade agreements (RTAs) to trade flow by applying gravity model. This paper research the impacts of regional trade agreements (RTAs) on commodity trade, with a particular focus on trade creation and diversion effects. They analyze the impacts of RTAs involving 67 countries for 20 commodities during time from 1980 to 2006. The conclusion shows that, the EU is shown to have a trade creation effect in trade of agricultural commodities, while the AFTA and the NAFTA have trade creation effects in machinery commodities.

Concerning to agricultural trade creation and diversion impacts of FTAs, Lin Sun and Michael R. Reed (2010), with purpose of dealing with heteroscedasticity and zero trade observations, trade creation and diversion effects are estimated using a Poisson Pseudo Maximum-Likelihood (PPML) estimator with various fixed effects. Generally, the gravity equation of export volume concluded GDP of exported and imported countries, its population, distance between them and other dummy variables namely colonial ties, sharing border and FTA. Especially, FTA dummy was divided 
into three forms which were FTA signed by exported and imported countries, FTA signed by exported country but not by imported country and FTA signed by imported country but not by exported country. The results for trade creation impacts of FTAs were also significant. Meanwhile, pure trade diversion in EU25, NAFTA and COMESA was also significant. There were significant pure trade creation found among EU15, EU25 and SADC. A new FTA could encourage businesses to accelerate their export platform and soon reach the third-party countries, but once the transition of FTA continues, member states will turn to be better markets and export creation will convert to export diversion (Sun \& Reed , 2010).

In 2015, Hiroyuki Taguchi (2015) conducted research on ASEAN-plus-one free trade agreements. In this estimation, they adopt a gravity model by using panel-data with fixed effects. The result showed that ASEAN-China FTA (ACFTA) has a trade creation between member countries, ASEAN-Korea FTA (AKFTA) and ASEAN-Japan FTA (AJFTA) also has trade creation, but the level of trade creation of these two agreements is lower than ASEAN-China FTA (ACFTA). He argues that the greater trade creation effect in ACFTA stems from tax-favorable policy and the reduction of non-tariff trade barriers of this agreement (Taguchi, 2015).

Moreover, Wahyudi Setia Darma, Fithra Faisal Hastiadi (2017) conducted research on trade creation and diversion of Indonesia in the food industry. With the aim to analyze the effect trade creation and trade diversion which occurs after Indonesia take part in this three free trade agreement for food industry. They conducted by using gravity model with trade flows data from 12 countries in the period of from 2005 to 2015 . The empirical results of this research shows that take part in three free trade agreement: ACFTA, AKFTA and AIFTA provides for Indonesia a positive effect of trade creation food products. The results show that there is trade creation among members country for all of agreements in this research (Darma \& Hastiad, 2017).

\section{METHODOLOGY}

\subsection{Methodology}

By using quantitative method to conduct this research, Gravity model with panel data is applied to evaluate the impact of ACFTA on trade diversion and trade creation of fruit industry. STATA is used to run the data of gravity model. Estimating empirical result using OLS estimator (Ordinary Least Squares) and GLS estimator (Generalized Least Squares) with one agreement which is ACFTA.

However, there is a problem related to the value of some observations with 0 leading to difficulties when using logarithms. So, we will automatically eliminate this observation.
We use the empirical model that is specify by (Reed, 2010) with a few small changes. We use the independent variable GDPPC instead of the GDP variable as used in their research.

The empirical model is described as followed:

$\operatorname{lnXijt}=\beta 0+\beta 1 \mathrm{LnGDPPCit}+\beta 2 \mathrm{LnGDPPCjt}+\beta 3$ $\operatorname{lnPOPit}+\beta 4 \operatorname{lnPOPjt}+\beta 5 \operatorname{lnDISij}+\beta 6$ Comlij $+\beta 7$ Colyij $+\beta 8$ Borderij $+\sum_{m} \gamma m F T A_{i j t}^{m}+\sum_{m} \lambda m F T A_{i t}^{m}+$ $\sum_{m} \omega m F T A_{j t}^{m}+\varepsilon v \mathrm{j}$

Export Flows (Xijt) is the export value from country $i$ to country $\mathrm{j}$ at time $\mathrm{t}$. Xijt is measurement by USD thousand. Data on these trade flows of the two countries reflect the actual situation of the two countries' trade situation, the increase or decrease of trade is clearly reflected in the trade flows between the two countries. The two countries are expected to increase their trade when Xij this year is larger than the previous year. This is the variable that most clearly shows the trade trends of countries over each period.

Distance (DISij) is distance between country $\mathrm{i}$ and $\mathrm{j}$. It is the physical distance between the exporting country and importing country. It is calculated from the CEPII Database and is expressed in kilometers. The distance variable presents the transportation cost that a country faces to export or import goods. In addition, it can also reflect the similarity in demand due to the common features of climate and topography as well as the close proximity in terms of culture and consumption habits. Concerning to the relationship between $\mathrm{Xij}$ and distance, some articles suggest that this variable may be negative in Xij equation. Distance can reduce trade flows due to the increase in transportation costs. The farther away the distance, the higher the transport cost so the lower the trade flow (Anthony Venables, 2012). The increase in distance increases import and export costs, and thus increases the cost of products. Therefore, the distance will negatively affect trade flowing into the host country.

Population (POPit) is population of exporting country $i$ (people) at time t. Population represents the supply of labor as well as the amount of demand of a country. The relationship between trade flows and population is ambiguous. Some articles suggest that countries with a high proportion of the population will export less because they must meet domestic demand before exporting abroad. In this case, more population will encourage importing countries instead of exports. In contrast, the coefficient of this variable can be positive in the equation $\mathrm{Xij}$ when most of the population is working in the field of fruit production, with such a large number of workers, the level of production will be greater and the amount of output for exports will be more.

Population (POPjt) is population of importing country $j$ (people) at time t. The relationship between $\mathrm{Xij}$ and POPi is ambiguous. The higher the population, the greater the demand for consumption for importing 
countries. So that, the importer population will influent positively trade flows into the export country. High population is also an opportunity for importing countries to conduct production instead of import.

Population growth in a country may affect to trade flows in two ways: supply and demand. On the supply side, population growth may lead to an increase in labor resources, ensuring the ability to produce export goods. While on the demand side, population growth will increase domestic consumption demand, which means an increase in imports (Dianniar, 2013)

Gross Domestic Product per capita (GDPPCit and GDPPCjt) is the best measurement of a country's standard of living. GDPPCit and GDPPCjt are measurement by million dollars. This variable reflects the purchasing power and affordability of consumers. It is also an indication of the level of development of a country to invest more in technology for the production process.

\section{Dummy Variables}

This study includes a few dummy variables such as: common language, common border, colonial relations, and free trade agreements (ACFTA).

Two countries $\mathrm{i}$ and $\mathrm{j}$ are said to have colonial relations when country $i$ is the nation's colony $j$, country $j$ is the nation's colony, or two countries $i$ and $j$ are simultaneously colonies of another country. The relationship between trade flows and language, border, colonial links is positive. If the two countries have the same language, the distance is close to each other, the former belongs to each other, the high ability in having similar culture, having common tastes and needs. Thus, these countries will be able to import each other's goods more than countries that are far away or have different cultures.

This table show the variables and their expected signs

Table 1. Variables and their expected signs

\begin{tabular}{|l|l|l|}
\hline Variable & Definition & $\begin{array}{l}\text { Expected } \\
\text { signs }\end{array}$ \\
\hline GDPPCi & GDP per capital of country $\mathrm{i}$ & + \\
\hline GDPPCj & GDP per capital of country $\mathrm{j}$ & + \\
\hline POPi & Population of country $\mathrm{i}$ & $+/-$ \\
\hline POPj & Population of country $\mathrm{j}$ & $+/-$ \\
\hline DISij & Distance between $\mathrm{i}$ and $\mathrm{j}$ & - \\
\hline Comlij & $\begin{array}{l}=1 \text { if } \mathrm{i} \text { and } \mathrm{j} \text { have a common } \\
\text { language }\end{array}$ & + \\
\hline Colyij & $\begin{array}{l}=1 \text { if } \mathrm{i} \text { and } \mathrm{j} \text { have colonial } \\
\text { relations }\end{array}$ & + \\
\hline Borderij & $\begin{array}{l}=1 \text { if } \mathrm{i} \text { and } \mathrm{j} \text { have a common } \\
\text { border }\end{array}$ & + \\
\hline ACFTAij & $=1$ if $\mathrm{i}$ and $\mathrm{j}$ both are members & + \\
\hline
\end{tabular}

\begin{tabular}{|l|l|l|}
\hline & of ACFTA & \\
\hline \multirow{2}{*}{ ACFTAj } & $\begin{array}{l}=1 \text { if country } \mathrm{j} \text { is a member of } \\
\text { ACFTA but country i isn't }\end{array}$ & - \\
\hline \multirow{2}{*}{ ACFTAi } & $\begin{array}{l}=1 \text { if country i is a member of } \\
\text { ACFTA but country } \mathrm{j} \text { isn't }\end{array}$ & - \\
\hline
\end{tabular}

(Source: Author, 2021)

\subsection{Data}

The sample used for this analysis totals 10 countries: In which, there are 5 large import and export countries of fruits in ACFTA agreement. The following five countries are: Vietnam, Thailand, Philippines, China, and Singapore. And there are five countries outside the ACFTA agreement, including two major fruit exporters worldwide are the United States and the Netherlands; and three major fruit importers worldwide are France, the United Kingdom and Germany. We use the STATA with a sample period from 2002 to 2016 includes four years before and eleven years after the signing of ACFTA. However, this observation can be decrease because logarithmic transformation of dependent variable or independent variable $=0$. In this case, this observation will be cancel. In addition, having some observations is duplicated, so that, this observation also will be cancel.

Data on export and import of fruit is taken from trade map (https://trademap.org), measured by USD thousand. Data on gross domestic product per capital (GDPPC) measured by million dollars, and Population data is taken from the World Bank Development Indicators database (https://www.worldbank.org/), and measured by people. Data on common language, common border, and colonial relationships come from the Centre d'Etudes Prospectives et d'Informations Internationales (http://www.cepii.fr/cepii/en/bdd_modele/bdd.asp). The data about distance, common language, common border and colonies are taken from the following two files: "GE O_C EPI IX LS and DIST_C EPI I.XLS". While the file GE O_C EPI IX LS give information information about the language General, common borders and colonial relations, the file DIST_C EPI I.XLS give file information about the geographical distance of countries from the capital to the capital. And database about ACFTA was collected from WTO Regional Trade Agreements (http://wtocenter.vn/). Data on distance come from (https://www.freemaptools.com/), measured by kilometers. Particular, Data on distance take from the capital of the exporting country to the capital of the importing country.

\section{RESULTS AND DISCUSSION}

This section is written to provide estimates and explanations. First, the OLS model is used to analyze panel data. Secondly, because OLS has some significant deviations, therefore, the GLS model is used to estimate. Finally, compare the results of the OLS model and the GLS model. 
The data of this research base on 5 member country of ACFTA and 5 non-member country of ACFTA for the period from 2002 to 2016 using the gravity model as mentioned earlier.

The estimated results of gravity equation are presented in Table 2. After checking for multicollinearity by pairwise correlation and variance inflation factor (VIF) tests, OLS regression is employed. However, the OLS estimator has heteroscedasticity and autocorrelation errors while applying White's general test and Wooldridge test. Hence, we continue to re-estimate two models by GLS regressions to handle these problems of OLS.

Table 2. The results of the OLS and GLS estimation

\begin{tabular}{|c|c|c|}
\hline \multicolumn{3}{|c|}{ Dependent variable $\ln X i j$} \\
\hline Variable & OLS Model & GLS Model \\
\hline \multirow[t]{2}{*}{$\operatorname{lnGDPPCi}$} & 0.0421 & -0.0150 \\
\hline & $(0.48)$ & $(-0.31)$ \\
\hline \multirow[t]{2}{*}{ LnGDPPCj } & -0.131 & 0.272 \\
\hline & $(-1.41)$ & $(3.28)^{* *}$ \\
\hline \multirow[t]{2}{*}{ LnPOPi } & 1.187 & 1.133 \\
\hline & $(13.52) * * *$ & $(17.47)^{* * *}$ \\
\hline \multirow[t]{2}{*}{$\operatorname{lnPOPj}$} & -0.889 & -0.258 \\
\hline & $(-6.05) * * *$ & $(-2.42) *$ \\
\hline \multirow[t]{2}{*}{$\operatorname{lnDISij}$} & 0.216 & -0.133 \\
\hline & $(0.82)$ & $(-0.70)$ \\
\hline \multirow[t]{2}{*}{ coml } & -1.348 & -0.323 \\
\hline & $(-4.42)^{* * *}$ & $(-1.62)$ \\
\hline \multirow[t]{2}{*}{ border } & 2.849 & 3.016 \\
\hline & $(6.37)^{* * *}$ & $(14.75) * * *$ \\
\hline \multirow[t]{2}{*}{ coly } & -1.307 & -0.422 \\
\hline & $(-3.62)^{* * *}$ & $(-1.59)$ \\
\hline \multirow[t]{2}{*}{ ACFTAij } & 1.326 & 1.316 \\
\hline & $(2.25)^{*}$ & $(3.34) * * *$ \\
\hline \multirow[t]{2}{*}{ ACFTAi } & 1.917 & 0.755 \\
\hline & $(6.01) * * *$ & $(4.22) * * *$ \\
\hline \multirow[t]{2}{*}{ ACFTAj } & -1.401 & -0.691 \\
\hline & $(-3.92)^{* * *}$ & $(-2.47) *$ \\
\hline \multirow[t]{2}{*}{ _cons } & 1.705 & -8.441 \\
\hline & $(0.46)$ & $(-3.36) * * *$ \\
\hline
\end{tabular}

Notes: *,** and ***: Level of significance of 10,5 and 1 percent respectively

(Source: Author, 2021)
OLS results show that, most of the variables are significant except for 3 variables: GDPPCi; GDPPCj and DISij. The variables showing a positive effect are POPi; border; ACFTAij and ACFTAi, while POPj; coml; coly show negative effects. Using GLS also gives similar results to OLS test. Most of the variables are significant except for 4 variables: GDPPCi; DISij; coml and coly. The variables showing positive effects are POPi; border; ACFTAij and ACFTAi, while POPj and ACFTAj show negative effects. Because OLS estimator have the problem of heteroscedasticity and autocorrelation. Therefore, we use GLS regressions to read the results.

Research by Lin Sun and Michael R. Reed (2010) is used to read GLS results. According to this research, if $\gamma \mathrm{m}>0$ and $\lambda \mathrm{m}>0$ or $\gamma \mathrm{m}>0$ and $\omega \mathrm{m}>0$, there is trade creation for imports (exports). Trade diversion is happened when $\gamma \mathrm{m}>0$ and $\lambda \mathrm{m}+\omega \mathrm{m}<0$ or $\gamma \mathrm{m}>0$ with $\lambda \mathrm{m}<0$ and $\omega \mathrm{m}<0$.

From the results of the OLS estimate, it can be seen that $\gamma \mathrm{m}=1,326>0 ; \gamma \mathrm{m}=1.917>0$ and $\lambda \mathrm{m}=-1.401>0$. While the results of the GLS estimate, it can be seen that $\gamma \mathrm{m}=1,316>0 ; \gamma \mathrm{m}=0.755>0$ and $\lambda \mathrm{m}=-0.691>0$. Both estimates give the same result as trade creation. Therefore, it can be concluded that there is trade creation between countries participating in the ACFTA free trade agreement.

\section{CONCLUSION}

Empirical results show that GDP of export countries has a positive influence on trade flows. This can be seen as an implication that rich countries, which have the ability to invest more in production technology, could create more valued products. As the result, it leads to a positive impact on exports. Although the GDP of import countries are insignificant, both the population of export and import areas have significant in this study. The population of export countries have a positive effect on trade flows, in contrast, the population of import countries have a negative effect. In fact, the population factor is very difficult to assess the needs or resources of a country. Migration and labour export situation is increasing day by day, leading to the distribution of labour resources from densely populated countries to less populated countries, which makes the population statistics not really reflect the true source of a country's labour. Consequently, it can be concluded that the size of income or population affects trade flows. Distance represents transport costs, but it is not significant in this case. It indicatesc that transportation costs are not a big barrier for export and import. Today, logistics operations have become smarter. When logistics operators know how to apply and combine multimodal transport and consolidation, logistics costs become more effective and economical. In addition, there is a factor that we need to consider is that the member countries in ACFTA are relatively close geographically, which also significantly reduces geographical barriers. Nextly, the common language and colony relations variables have 
insignificant coefficients on trade flows. In the Context of Globalization, language is not a difficult barrier for countries to conduct commerce, because of the popularity of English. The current level of education has been greatly improved. Currently, there are a lot of formal training classes in foreign languages, investments in education and in particular languages are increased, so the number of citizens could approach a variety of languages. While the common border factors influence trade positively, ACFTA also has a positive impact on trade flows. The proper policy implication that can be considered from this study is that member countries of ACFTA should try to use tax incentives to increase trade flows between them, specifically related to fruit industry. The government of member countries should take correct measures to increase trade volume with others. Moreover, it is necessary to continue maintaining a high level of trade with existing partner countries

Based on the estimation results in this study, some conclusions can be drawn that: participation in ACFTA has an impact on member countries' trade, particularly positive impacts on fruit industry. This suggests that the implementation of ACFTA could make a trade creation by increasing intra-regional trade of the fruit industry among the ACFTA members.

The increase in intra-regional trade with ACFTA is the result of preferential tariffs that are applied between ACFTA members. Furthermore, the estimated results of this study also imply that trade creation from the implementation of ACFTA could provide a significant opportunity for accessing China's fruit market. The participation of VietNam in ACFTA has positive impacts on the export of the fruit industry. Therefore, it is necessary to create long-term advantages, improve competitiveness, continue and strengthen this partnership in the direction of bringing more benefits. By improving both product quality, packaging, preserving goods and taking the advantage of logistics combination, Vietnamese enterprises can bring their goods which has comparative advantages in both quality and price to compete with other countries in the region.

As mentioned above, one of the reasons for the above trade creation is a conversion of the origin of goods to attain tax incentives. This case will cause a misunderstanding of trade creation due to the increase of trade flows between countries. The conversion of origin of goods can be described as follows: Fruit products, particularly bananas from Laos if exported directly to China, will be applied higher tariffs than Vietnamese bananas are exported to China. Thus, that causes price padding, increasing the price of bananas in Laos. Hence, traders often import bananas from Laos into Vietnam with $\mathrm{C} / \mathrm{O}$ form $\mathrm{D}$ to get 0 percent tax incentives under the CEPT agreement. After that, they used those banana products to export to China with $\mathrm{C} / \mathrm{O}$ form $\mathrm{E}$ to get the preferential tariff rate under the ACFTA agreement. In such a case, Vietnamese goods are not actually exported, while Lao goods are exported twice in a row and the trade flows represent Vietnamese goods exported to China. These cases are considered illegal and affect the export of fruit products of Vietnam. Therefore, it is necessary to have solutions to prevent this problem. Governments of countries must have strict regulations for issuing the certificate of origin and require complete business records. When being in doubt, the authorities, who approve the application for certification of origin, need directly come to production facilities and farms for inspection.

One of the shortcomings of this study is that it ignores how exchange rate changes affect trade flows between countries. Hopefully, this article is valuable for your reference and future studies can supplement the shortcomings in this study.

\section{REFERENCES}

[1] Morais, A. \& Bender, S. (2003). "Trade Creation And Trade Diversion In Mercosur And Nafta". NEP Reports.

[2] Akram, M. \& Rashid, A. (2017). "Trade Creation and Diversion Effects of the European Union". Pakistan Journal of Applied Economics.

[3] Amuliibale, D. (2014). "Trade creation Trade diversion: Estimates of Trade Effets of COMESA's Expansion". International and development economics.

[4] Anderson, J. E. (1979). "A Theoretical Foundation of the Gravity Model". American Economic Review.

[5] Anderson, J. E., and Wincoo, E. (2003). "A Solution to the Border Puzzle". American Economic Review.

[6] Bodea, A. (2016). "Trade creation and trade diversion in the EU periphery: the case of the North East region of Romania" . Faculty of Economics and Public Administration.

[7] Burger, M. J., Oort. F, and Linders. G, (2009). "On the Specification of the Gravity Model of Trade: Zeros, Excess Zeros and Zero-Inflated Estimation". Spatial Economic Analysis .

[8] Chaney, T. (2011). "The Network Structure of International Trade". Centre for Economic Policy Research.

[9] Dalimov, R. (2009). "The Dynamics of Trade Creation and Trade Diversion Effects Under International Economic Integration". Current Research Journal of Economic Theory.

[10]Darma, W. S., \& Hastiad, F. F. (2017). "Trade Creation and Trade Diversion Effects of the ASEAN-China Free Trade Agreement, ASEAN-Korea Free Trade Agreement, and ASEAN-India Free Trade Agreement Implementation on the Export of Indonesia's". International Journal of Economics and Financial Issues.

[11]Deardorff, A. (1998). "Determinants of Bilateral Trade: Does Gravity Work in a Classical World?" The Regionalization of the World Economy.

[12]Dianniar, U. (2013). "The Impact of Free Trade Agreements on Indonesia's Agricultural Trade 
Flows: An Application of the Gravity Model Approach". Institute of Social Studies.

[13] Eichengreen, B., and D. A. Irwin. (1998). "The Role of History in Bilateral Trade Flows. NBER Chapters. In: The Regionalization of the World Economy, ed. Jeffrey Franke". University of Chicago Press.

[14] Kendall, L. \&. (2007)."Trade creation and trade diversion: analyzing the impact of regional trade agreements". London Edward Elgar.

[15] Krueger, A. O. (1999). "Trade creation and trade diversion under NAFTA". NBER Working Paper.

[16] Kyoji, F., Toshihiro, O., \& Stern, R. (2003). "An econometric analysis of trade diversion under NAFTA". The North American Journal of Economics and Finance.

[17] Khoi, C. (2017, 12 26). "Xuất khẩu rau quả lập kỷ lục". VnEconomy .

[18] Lee, J.-W., and P. Swagel. (1997). "Trade Barriers and Trade Flows across Countries and Industries". Review of Economics and Statistics.

[19] Phuong, L. (2017, 01 25). "Fruit and vegetables are export highlights". VietNam Economy News.

[20] Reed, L. S. (2010). "Impacts of Free Trade Agreements on Agricultural Trade Creation and Trade Diversion". American Journal of Agricultural Economics.

[21] Sattayanuwat, W. (2017). "Trade Creation and Trade Diversion of ASEAN's Preferential Trade Agreements". IAFOR Journal of the Social Sciences.

[22] Sun, L., \& Reed , M. (2010). "Impact of Free Trade Agreements on Agricultural Trade Creation and Trade Diversion". American Journal of Agricultural Economics.

[23] Taguchi, H. (2015). "Trade creation and diversion effects of ASEAN-plus-one free trade agreements". Economics Bulletin.

[24] Tinbergen, J. (1962). "Shaping the World Economy: Suggestions for an International Economic Policy". Royal Economic Society.

[25] The ministry of financial. (2015). "Giới thiệu chung ACFTA". Retrieved from http://www.mof.gov.vn

[26] Trademap.org. (2018). VCCI. Retrieved from Trademap.org.

[27] Trefler, D. (n.d.). "Trade Liberalization and the Theory of Endogenous Protection: An Econometric Study of U.S. Import Policy" . Journal of Political Economy.

[28] Viner, J. (1950). "The Customs Union Issue. Carnegie Endowment for International Peace".

[29] Yin, H. S. (2010). "The impact of ASEAN free trade area on intra-ASEAN manufacturing trade". International Journal of Business and Society.

\section{APPENDIX}

Appendix 1: Correlation relationship between independent variables

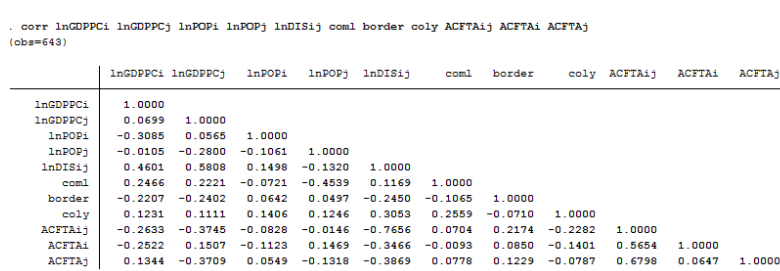

(Source: Author, 2021)

Appendix 2: The results of the OLS estimation

\begin{tabular}{|c|c|c|c|c|c|c|}
\hline Source & ss & $d f$ & ms & \multirow{4}{*}{\multicolumn{2}{|c|}{$\begin{array}{ll} & \text { Number of obs } \\
& \text { F(11, 631) } \\
3 & \text { Prob }>\text { F } \\
4 & \text { R-squared } \\
& \text { Adj R-squared }\end{array}$}} & \multirow{4}{*}{$\begin{array}{r}643 \\
51.00 \\
0.0000 \\
0.4706 \\
0.414 \\
2.2545\end{array}$} \\
\hline Mode 1 & 2851.19915 & 11 & 259.199923 & & & \\
\hline Residual & 3207.14883 & 631 & 5.08264474 & & & \\
\hline Tota1 & 6058.34798 & 642 & 9.4366791 & & & \\
\hline $\ln X_{i j}$ & Coef. & Std. Err. & t & $p>|t|$ & [954 Cont & nf. Interval] \\
\hline InGDPPCi & .0421438 & .0886969 & 0.48 & 0.635 & -.132033 & .2163206 \\
\hline 1nGDPPCj & -.1309664 & .0925682 & -1.41 & 0.158 & -.3127455 & .0508126 \\
\hline 1nPOPi & 1.186962 & .0877639 & 13.52 & 0.000 & 1.014618 & 1.359307 \\
\hline InPOPj & -.8893202 & .1470923 & -6.05 & 0.000 & -1.17817 & $\begin{array}{ll}7 & -.6004705\end{array}$ \\
\hline InDISij & .2161941 & .2642263 & 0.82 & 0.414 & -.3026751 & $1 \quad .7350633$ \\
\hline com1 & -1.348408 & .3052792 & -4.42 & 0.000 & -1.947895 & $5 \quad-.7489222$ \\
\hline border & 2.848566 & .447209 & 6.37 & 0.000 & 1.970368 & $\begin{array}{l}8.726764 \\
8\end{array}$ \\
\hline & -1.306599 & .360609 & -3.62 & 0.000 & -2.014738 & -.59846 \\
\hline ACFTAij & 1.325618 & .5892531 & 2.25 & 0.025 & .1684832 & 2.482752 \\
\hline ACFTAi & 1.916796 & .3190118 & 6.01 & 0.000 & 1.290342 & 2.543249 \\
\hline ACFTAj & -1.401448 & .3579139 & -3.92 & 0.000 & -2.104294 & $\begin{array}{ll}4 & -.6986013\end{array}$ \\
\hline _cons & 1.705341 & 3.737099 & 0.46 & 0.648 & -5.633315 & 9.043997 \\
\hline
\end{tabular}

(Source: Author, 2021)

Appendix 3: The VIF results for the regression vif

\begin{tabular}{r|rr} 
Variable & VIF & $1 / \mathrm{VIF}$ \\
\hline ACFTAij & 9.80 & 0.102051 \\
lnDISij & 5.36 & 0.186670 \\
ACFTAj & 4.04 & 0.247324 \\
ACFTAi & 3.05 & 0.327334 \\
lnGDPPCj & 2.55 & 0.391420 \\
lnGDPPCi & 2.53 & 0.395104 \\
Coml & 1.80 & 0.555201 \\
lnPOPj & 1.77 & 0.563434 \\
lnPOPi & 1.48 & 0.675720 \\
Coly & 1.39 & 0.718469 \\
border & 1.13 & 0.888583 \\
\hline Mean VIF & 3.17 &
\end{tabular}

(Source: Author, 2021) 
Appendix 4: The result from White's test

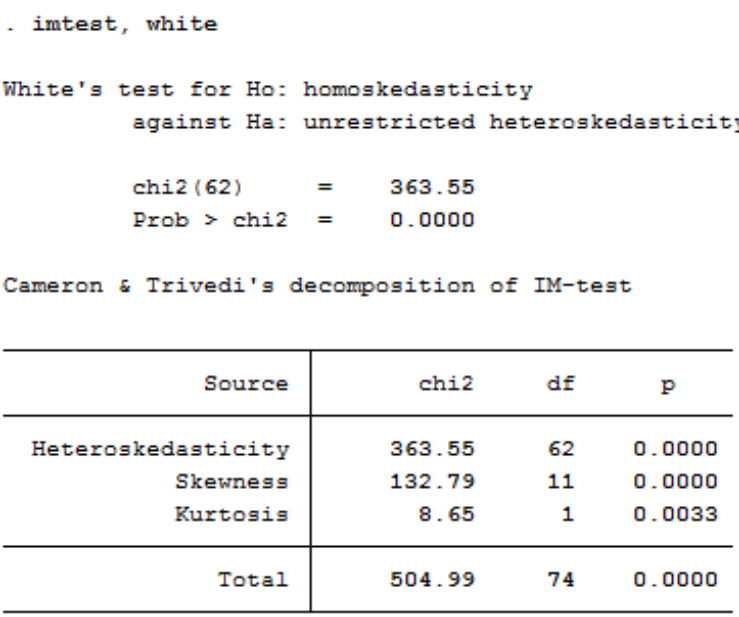

Appendix 5: The result from autocorrelation test

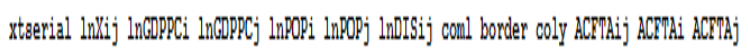

Nooldridge teast tor autocoorelelation in panel data

80: no tirgt-order autocorrelation

$$
\begin{aligned}
\text { I) 1, } \quad 42)=10.676 \\
\text { Prob }>\text { ? }=0.0022
\end{aligned}
$$

Appendix 6 The results of the GLS estimation

\begin{tabular}{|c|c|c|c|c|c|c|}
\hline $\ln x i j$ & Coef. & Std. Brr. & $z$ & $\mathrm{p}>|z|$ & [958 Conf. & Interv \\
\hline 1nGDPPCi & -.0145 & .047 & -0.31 & 0.754 & -.108 &  \\
\hline InGDPPC & .2715 & .0826899 & 3.28 & 0.001 & & .4336282 \\
\hline InPOPi & 1.13288 & .0648545 & 17.47 & 0.000 & 1.005767 & 1.259992 \\
\hline InPOPj & -.2584117 & .106 & -2.42 & 015 & -.4675968 & -.0492265 \\
\hline InDISij & -.132797 & & -0.70 & 0.485 & & \\
\hline $\mathrm{com}$ & -.3231995 & .1993758 & -1.62 & 0.105 & -.7139689 & .0675698 \\
\hline bore & & .204 & 14.75 & 0.000 & 2.61513 & 3. \\
\hline & -.4216193 & .2656 & -1.59 & 0.113 & -.9423705 & . 0991319. \\
\hline $\mathrm{ACZ}$ & 1.31 & .393 & 3.34 & 0.001 & .5443264 & 2.088054 \\
\hline ( & .7 & .178 & 22 & 0.000 & 040636 & 1.105678 \\
\hline ACFTAj & -.6914 & .279819 & -2.47 & 0.013 & -1.239854 & -.1429834 \\
\hline . & -8.441306 & 2.511276 & -3.36 & 0.001 & -13.36332 & -3.519296 \\
\hline
\end{tabular}

$$
\begin{aligned}
& \text { xtg1s lnXij 1nGDPPCi 1nGDPPCj InPOPi InPOPj 1nDISij coml border coly ACFTAij ACFTAi ACFTAj, pane1s (h) } \\
& \text { Cross-sectional time-series FGLS regression } \\
& \text { Coefficients: generalized least squares } \\
& \text { Pane1s: heteroskedastic } \\
& \text { no autocorrelation } \\
& \text { Estimated covariances }=43 \quad \text { Number of obs }=643 \\
& 0 \\
& \text { Estimated coefficients }=12 \text { Obs per group: }{ }_{\min }=14 \\
& \begin{array}{rr}
\text { avg }= & 14.95349 \\
\max = & 15
\end{array} \\
& \text { Wa1d chi2(11) }=\begin{array}{rr}
\max & 1229.65 \\
& =0.0000
\end{array}
\end{aligned}
$$

\begin{tabular}{|c|c|c|}
\hline & $\begin{array}{r}\text { (1) } \\
\ln x i j\end{array}$ & $\begin{array}{r}\text { (2) } \\
\ln X_{i j}\end{array}$ \\
\hline InGDPPCi & $\begin{array}{l}0.0421 \\
(0.48)\end{array}$ & $\begin{array}{r}-0.0150 \\
(-0.31)\end{array}$ \\
\hline lnGDPPCj & $\begin{array}{l}-0.131 \\
(-1.41)\end{array}$ & $\begin{array}{l}0.272 * * \\
(3.28)\end{array}$ \\
\hline InPOPi & $\begin{array}{c}1.187 * * * \\
(13.52)\end{array}$ & $\begin{array}{c}1.133^{* * *} \\
(17.47)\end{array}$ \\
\hline InPOPj & $\begin{array}{l}-0.889 * * * \\
(-6.05)\end{array}$ & $\begin{array}{l}-0.258^{*} \\
(-2.42)\end{array}$ \\
\hline InDISij & $\begin{array}{r}0.216 \\
(0.82)\end{array}$ & $\begin{array}{l}-0.133 \\
(-0.70)\end{array}$ \\
\hline $\operatorname{com} 1$ & $\begin{array}{l}-1.348 * * * \\
(-4.42)\end{array}$ & $\begin{array}{l}-0.323 \\
(-1.62)\end{array}$ \\
\hline border & $\begin{array}{l}2.849 * * * \\
(6.37)\end{array}$ & $\begin{array}{l}3.016 * * * \\
(14.75)\end{array}$ \\
\hline $\operatorname{col} y$ & $\begin{array}{l}-1.307 * \pi * \\
(-3.62)\end{array}$ & $\begin{array}{l}-0.422 \\
(-1.59)\end{array}$ \\
\hline ACFTAij & $\begin{array}{l}1.326 * \\
(2.25)\end{array}$ & $\begin{array}{l}1.316 * * * \\
(3 \cdot 34)\end{array}$ \\
\hline ACFTAi & $\begin{array}{l}1.917 * * * \\
(6.01)\end{array}$ & $\begin{array}{l}0.755 * * * \\
(4.22)\end{array}$ \\
\hline $\mathrm{ACFTAj}$ & $\begin{array}{l}-1.401 * * * \\
(-3.92)\end{array}$ & $\begin{array}{l}-0.691 * \\
(-2.47)\end{array}$ \\
\hline - cons & $\begin{array}{l}1.705 \\
(0.46)\end{array}$ & $\begin{array}{l}-8 \cdot 441 * * * \\
(-3 \cdot 36)\end{array}$ \\
\hline
\end{tabular}

Appendix 7 The results of the OLS and GLS estimation esttab pool gla 